\title{
The Impact of Ethics \& Objectivity of Internal Audit Personnel on Transparency \& Accountability Case of Zimbabwe Local Authorities
}

\author{
Moses Jachi ${ }^{1} \quad$ Lucky Yona $^{2 *}$ \\ 1. Midlands State University P. Bag 9055, Gweru, Zimbabwe \\ 2. Eastern and Southern African Management Institute P.O. Box 3030, Arusha, Tanzania
}

\begin{abstract}
The study aimed at examining the impact of Ethics \& Objectivity of Internal Audit Function on transparency and accountability. The study adopted ethics \& objectivity (as determined by internal auditors' personal needs strength and enhanced by the Chief Audit Executive's leadership style), as the independent variable and transparency \& accountability as the dependent variable. The effect of internal audit function on transparency \& accountability was assessed through management perception, organization policy, auditees' cooperation and risk exposure of the organization. Survey data was obtained from a sample of 182 internal audit and management personnel from local authorities in Zimbabwe using semi-structured questionnaires. Correlation and regression analysis were used to test the hypothesis that internal audit function ethics \& objectivity is positively associated with transparency and accountability. Study findings reveal that internal audit function ethics \& objectivity is positively associated with transparency \& accountability. The study established the need to improve operational paradigms guiding internal audit in Zimbabwe local authorities so as to empower internal audit functions and ensure they judiciously act in the best interest of the public, especially in circumstances where the general ethical conduct of their respective local authorities is defective and against public interest.
\end{abstract}

Keywords: Ethics \&Objectivity, Internal Audit Function, Transparency \& Accountability

DOI: $10.7176 / \mathrm{EJBM} / 11-7-09$

Publication date:March $31^{\text {st }} 2019$

\section{Introduction}

Ease of accessing information obtained by a government is a concern for every taxpayer (Neu, et al., 2013; Roussy \& Brivot, 2016), because of the strong linkages that exist between transparency and ethical issues concerning corruption and administrative deviations (Piotrowski \& Bartelli, 2010; Adiputra, et al., 2018). Ethics as a philosophical concept refers to a branch of knowledge that deals with ideal human behaviour, which relates to practices that result in highest levels of well-being (Billington, 2003). Applied in business context on a broader perspective, ethics concerns ideal practices and decisions by corporate players founded from a moral framework (Pinnington, et al., 2007), within which the ethical and unethical parameters are defined in the context of justice and humanity (Kinicki \& Williams, 2013; MacDougall, et al., 2015). Billington (2003) outlined crucial tenets about ethics and morals, asserting that individuals cannot avoid making moral or ethical choices because societal connections call for moral and ethical actions (Billington, 2003). This entails that a rational internal auditor has an ethical and moral obligation to make an objective decision because the position he hold arouses societal expectations for him to act like wise (Billington, 2003; Carmichael, 2004; Holt \& DeZoort, 2009; Christopher, et al., 2009; West, 2017).

Objectivity of internal audit personnel is a personal trait that enables them to maintain impartiality, eliminate bias and safeguarding against conflict of interests (Abu-Azza, 2012). The Institute of Internal Auditors' International Standards for the Professional Practice of Internal Audit overemphasise on the close relatedness of the concept of objectivity to independence (IIA, 2016). However, considering the extent of non-audit services resident internal auditors are usually associated with, the unavoidable personal relationships that build with people working together (Venasco, 1994; Kimotho, 2014), the question remains as to how a resident internal auditor can significantly hinge on independence for objectiveness. The increased recognition of the role of internal audit services towards more of a management-service (Kimotho, 2014; Roussy \& Brivot, 2016) which comes with commensurate familiarity and social pressure threats requires a different view of the sources of strength of internal auditor objectivity towards an ethics bias than independence.

With the recently gained significance of internal audit to the organizational governance processes (Jennnings, 2003; Brown, et al., 2003; Moeller, 2004; IIA, 2016), it can be appreciated that the performance of auditors is not only being affected by their special skills, organizational setups, but also by their ethical decision making ability (Woodbine \& Liu, 2010). In practice, the ethical standards of internal auditors are often challenged by dilemmas involving split loyalty, the expectation gap and conflict of interests between various parties (Venasco, 1994; Larking, 2000; Woodbine \& Liu, 2010). The recent developments within the internal audit profession have motivated a number of studies in to the profession tasks and activities. However, no much research has focused on 
whether codes guiding the professionals' ethical behavior have any influence on their moral perceptions (West, 2017). As a result, there is no justification to deny the importance to the profession of establishing whether there are any other principal domain drivers of ethical behavior (Woodbine \& Liu, 2010). Bass (1990), as quoted in Woodbine \& Liu (2010) pointed that the satisfaction and motivation of internal audit personnel is significantly influenced by their personal needs and reinforced by the behavior of the head of the internal audit function (Woodbine \& Liu, 2010; Dal Mas \& Barac, 2018).

Woodbine \& Liu (2010) in their study explored the importance of leadership style on internal auditor motivation towards moral behavior in Western Australia. The study concludes that the moral choices of internal auditors can be explained by their personal needs strength and reinforced by their supervisors' leadership style, supporting the Path-goal (House \& Mitchel, 1974) and the Existence, Relatedness and Growth (ERG) (Aldefer, 1972) theories. The study explored an uncharted area using traditional motivation theories that still has relevant applicability in the contemporary business environment. Based on the foundation and the results from this study conducted in Australia, the current study seeks to add to existing literature by further exploring how leadership style of Chief Audit Executives and personal needs strength (Woodbine \& Liu, 2010), as domain drivers of moral behavior motivation for internal auditors affects transparency and accountability in a developing world set up through its application to the Zimbabwean local government sub-sector.

\section{Statement of the problem}

Individual moral choices and values have a significant impact on groups and their individual members' objectiveness, thus there is a strong link between personal values, beliefs and behaviour (Badaracco \& Ellsworth, 1991; Demidenko \& McNutt, 2010; Sison \& Fontrodona, 2012; West, 2017) of individual auditors and the quality of the entire internal audit function. Notwithstanding the importance of ethics in the execution of internal auditors' duties (O'Leary \& Stewart, 2007), very few studies, and non in the context of Zimbabwe local government subsector, has investigated on how ethical decision making ability (Dittenhoffer \& Klemn, 1983; Arnold \& Ponemon, 1991; Dittenhoffer \& Sennetti, 1994; Larking, 2000; O'Leary \& Stewart, 2007; Chambers \& Odar, 2015) and moral choices of individual auditors as key objectivity dimensions (Woodbine \& Liu, 2010), affect the internal audit function's effectiveness in influencing good corporate governance practices. This study aims to make an important contribution to existing literature, through establishing the impact of ethics \& objectivity on transparency \& accountability in Zimbabwe local authorities.

\section{Literature review}

\subsection{The new institutional theory}

The New Institutional theory recognises internal audit as an important component of organisational governance structures. It provides an insight into the process through which internal audit functions' practices and developments are institutionalised through regulation and influence of professional organisations (DiMaggio \& Powel, 1983). This perspective helps to explain how internal audit functions develop and evolve through deinstitutionalisation of old and institutionalisation of new practices (Arena \& Azzone, 2007; Mihret, et al., 2010) and related changes in institutional norms (Carruthers, 1995; Deegan \& Unerman, 2006). The Institutional theory has been used to aid the understanding of organisational behaviour in a number of studies in the context of public sector organisations such as local governments (Mezias, 1990; Falkman \& Tagesson, 2008; Pina, et al., 2010), and to further the understanding of the design of internal audit functions and their effectiveness (Al-Twaijry, et al., 2003; Arena, et al., 2006; Arena \& Azzone, 2007; Mihret, et al., 2012).

The new institutional theory explains that organisations seek legitimacy by adopting commonly accepted norms and practices. This inter-dependence results in organisations influencing each other to act in a common fashion (DiMaggio \& Powel, 1983). Previous studies have employed the institutional theory to justify the existence and explain the developments within the internal audit profession. It has been established from a study conducted by Al-Twaijry et al (2003) in Saudi Arabia that the embracing of the need for internal audit functions within Saudi Arabian listed firms was merely a response to regulatory requirements (Al-Twaijry, et al., 2003). However, the study further established that practices within member firms were inconsistent as there was limited compliance to standards regulating the profession (Al-Twaijry, et al., 2003). The same findings were established from related studies analysing the attributes of internal audit functions in Italy (Arena, et al., 2006; Arena \& Azzone, 2007). The studies established that the existence of internal audit functions was influenced by regulation and listing requirements of the New York Stock Exchange. Christopher et al, (2009) also contributed to the notion by pointing that the establishment of internal audit functions in Italy was also a response to stakeholder expectations. They pointed that, internal audit functions were perceived to be playing a significant role in governance through their control role since the outbreak of corporate reporting scandals. Hence, it is up to the expectation of stakeholders that organisations establish internal audit functions to assure stakeholders that controls are in place (Christopher, et al., 2009).

This theoretical review helps in understanding the background, need, developments and role of internal audit 
functions within organisations. It has been established from the review that the scope of internal audit activities is significantly influenced by the need to meet societal expectations as a tacit responsibility placed upon the function by stakeholders (Limperg institute, 1985). The internal audit function exists in an organisation as a necessary contracting cost to signal the principal that the agents' activities are in line with organisational goals (Adams, 1994), and the related costs are incurred by management as a means of satisfying the demand for accountability by external stakeholders (Sherer \& Kent, 1983). Also, the developments within internal audit functions are a direct result of changes in institutional norms (DiMaggio \& Powell, 1983). These theories point to the value of internal audit functions within an organisation's governance frameworks.

The New Institutional Theory is important to the study of the relationship between ethics \& objectivity and transparency \& accountability. It can be argued that relative convergence around good ethical and moral choices is higher in highly ethical environments than in less ethical environments, as observations has failed to prove in contrary to the argument that "relative convergence around good governance is higher in good governments than in less good governments" (DiMaggio \& Powel, 1983). The argument focuses on public financial management systems in good governments, pointing to the notion that good governments look the same, and constitutes an identifiable component of institutional life (DiMaggio \& Powell, 1983). This study will focus on ethics and objectivity as an important internal audit function quality dimension that influences the degree of transparency and accountability in local authorities. The use of such a specific measure enables comparison of local authority systems with regard to applicability since they resemble common institutional features.

\subsection{Internal audit function ethics and objectivity}

Ethical or moral uprightness of an individual does not only point to an attitude that is not capable of being corrupted or committing fraud, but has more to do with traits of an individual or a group of individuals that resembles compliance with acceptable norms, values, rules and standards on face of the society, or organization (Bauman, 2013). The exploration in to the association between internal auditor ethics and objectivity and corporate governance is based upon a study by Woodbine \& Liu (2010). Findings from the study by Woodbine \& Liu (2010), which supports the Path-goal and the Existence Relatedness and Growth theories concludes that the moral choices of internal auditors can be explained by personal needs strength and demographic variables and reinforced by their supervisors' leadership style. These constructs collectively define the ethical nature of individual internal auditors, which in turn has a leading impact on internal audit function's objectivity. In contrary to the findings by Christopher (2014), the study alludes that audit charters and codes of conduct might be in place to help in the recognition of ethical issues, but however, much still depends on the individual auditor's motivation to make appropriate moral choices in any given circumstance. Christopher (2014) conducted a study to establish how internal audit functions enhance governance in Australian universities. The study established that the universities in Australia have a wider scope of tasks at their stake; the universities internal audit charter plays a significant role in guiding audit task performance and guiding moral behavior (Christopher, 2014). The study by Woodbine \& Liu (2010) however asserts that moral choices of individual auditors will overly determine the ethical nature of the entire internal audit function and that would in turn determine the overall nature of the internal audit function objectivity.

As a result of the recent developments within the internal auditing profession, it is evident that considerable efforts have been made to ensure the profession plays an important role in improving corporate governance and restore stakeholder confidence (Bou-Raad, 2000; Jennnings, 2003; Brown, et al., 2003; Moeller, 2004; Van Gansberhe, 2005). As such, internal auditors are faced with unique ethical dilemmas that call for moral decision making (Larking, 2000; Goodwin \& Yeo, 2001; Thompson, 2003; Woodbine \& Liu, 2010). The ethical nature of an internal audit function as a quality dimension which impacts objectivity will be determined by the aggregated individual internal auditors' moral choices to be measured by questionnaire. The isolated attributes determining the moral choices of internal auditors hence the ethical nature of the function will be assessed through individual internal auditors' personal needs strength and the Chief Audit Executive's leadership styles at the workplace (Woodbine \& Liu, 2010). With reference to prior studies on ethics, internal audit function attributes and the subsequent effect of having an objective audit function on organization governance processes, this study expects to establish a positive significant relationship between internal audit function ethics \& objectivity and transparency $\&$ accountability.

\subsection{Transparency and accountability in Zimbabwe local authorities}

Transparency is a critical pillar in model and modern governance, because it guarantees access and freedom of every stakeholder to obtain the most needed governance information (Medina, 2012). Transparency is important and initiatives to improve its levels in Zimbabwe local authorities is critical, as this will help de-horn corruption, minimize misuse of public resources (Adiputra, et al., 2018) that has dominated the sub-sector (CHRA, 2014) and results in subsequent improvement in service delivery. Local governments as agents of communities in public resources management need to observe highest level of transparent accountability (Hall \& Ferris, 2011; Hall, et 
al., 2015; Adiputra, et al., 2018). In this context, accountability refers to the local authority's response to the community on issues concerning their performance (Pina, et al., 2010). Internal audit functions when properly positioned within the organization, has a greater potential to positively impact transparency and accountability, as accountability is highly likely to materialize if requested from a position of authority (Lindberg, 2013; Steinbauer, et al., 2014; Pearson \& sutherland, 2017).

\section{Conceptual framework}

The conceptual framework was developed from a critical analysis of previous studies on internal audit and corporate governance. Prior studies on internal audit and organizational performance point to the existence of a positive relationship between internal audit function objectivity and corporate governance (Paape, et al., 2003; Christopher, et al., 2009; Sarens \& Christopher, 2010; Ibrahim, 2011); in turn, related studies reveal that internal audit objectivity is a function of internal audit personnel's moral and ethical values (Larking, 2000; Woodbine \& Liu, 2010; West, 2017). This notion motivates the current study, and therefore it hypothesizes that internal audit function ethics and objectively is positively associated with, and significantly promotes transparency and accountability. This relationship is illustrated in Fig 1 below;

\section{INDEPENDENT VARIABLE \\ DEPENDENT VARIABLE}

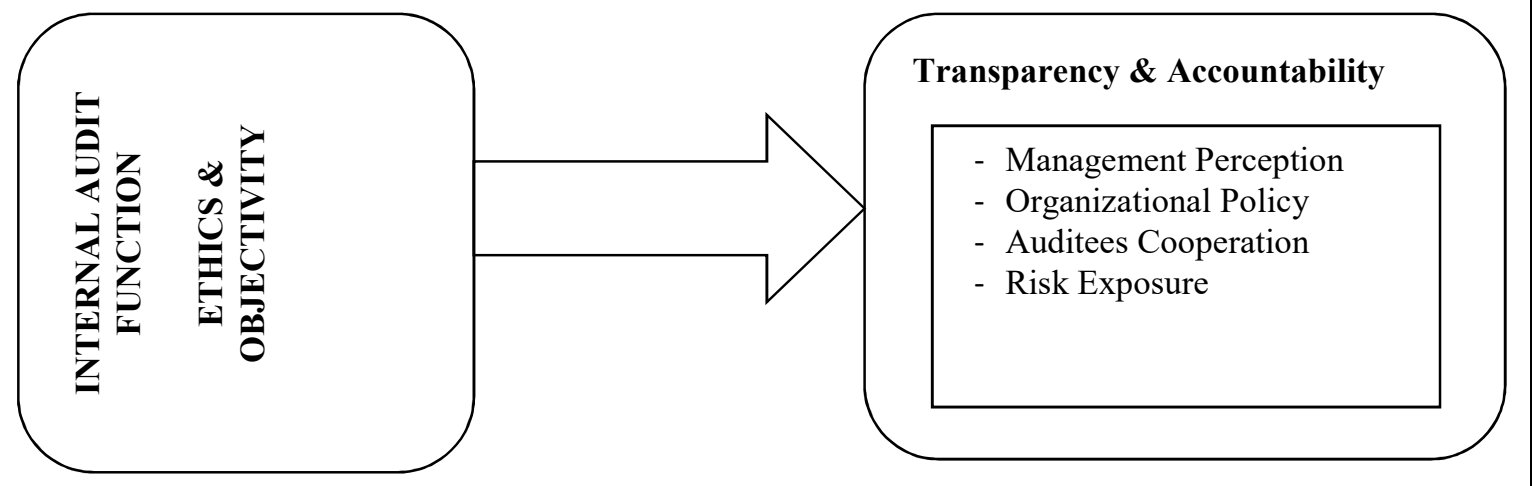

Figure 1. Study Conceptual Framework

Source: Researcher conceptualization, 2019

\subsection{Measuring the independent variable - Ethics \& Objectivity}

Ethics \& objectivity was measured by internal audit practitioners' views on a 5-point Likert-type scale, using specific items pertaining to leadership styles and personal needs strength (Woodbine \& Liu, 2010; Christopher, 2014). The independent variable was assessed through questionnaires that were measured on a 5-point Likert-type scale ranging from "Strongly Agree" to "Strongly Disagree" or "Always" to "Never" depending on the nature of the items for each dimension. Internal audit practitioners (chief audit executive and internal audit staff) were asked to indicate their opinions about internal audit ethics and objectivity in their local authorities.

\subsection{Measuring internal audit effectiveness in enhancing transparency $\&$ accountability}

Internal audit effectiveness in enhancing transparency \& accountability for the purpose of this study was assessed through a 5-point Likert-type scale questionnaire on management's perceptions on specific items about internal auditors' role within their respective local authorities. The questionnaire also assessed the extent to which management implement internal audit recommendations. Literature points to the difficulties of measuring internal audit effectiveness in upholding governance processes and the absence of a generally agreed approach for measurement (Arena \& Azzone, 2009; Noble, 2010; Erasmus \& Coetzee, 2018). However, as Arena and Azzone (2009) pointed out, the use of internal audit recommendation by management as an outcome measure (Roussy \& Brivot, 2016; Erasmus \& Coetzee, 2018) and the level of implementation of internal audit recommendations can be used as some of the objective measures of internal audit effectiveness (Sawyer, 1995; Van Gansberhe, 2005; Mihret \& Yismaw, 2007; Arena \& Azzone, 2009). The use and level of application of audit recommendation reflects on management support of the internal audit function. Internal audit literature points to the criticalness of management support in determining effectiveness of internal audit functions (Gramlin, et al., 2004; Sarens \& De Beelde, 2006a; Mihret \& Yismaw, 2007; Christopher, et al., 2009; Halimah, et al., 2009; Cohen \& Sayag, 2010).Management perceptions on internal auditor's role in transparency and accountability were sought in terms of perceived risk exposure and management's action on internal audit recommendations (Cooper, et al., 1994; Arena \& Azzone, 2009; Mihret, et al., 2010; Aziz, 2013). 


\section{Research methodology}

Five sets of data collection instruments were employed as depicted in the table below:

Table 1: Data Collection Instruments

\begin{tabular}{|l|l|l|}
\hline Instrument set & Instrument form & Targeted class of respondents \\
\hline Instrument set (i) & Questionnaire & $\begin{array}{l}\text { Internal Audit Practitioners(Chief Audit } \\
\text { Executives and Audit Staff) }\end{array}$ \\
\hline Instrument set (ii) & Questionnaire & Senior Management \\
\hline Instrument set (iii) & Document review guide & Secondary Data \\
\hline
\end{tabular}

Source: Researcher, 2019

Instrument set (i) is a questionnaire for internal audit personnel. Items are grouped under subheadings to assist participants gain easy grasp of questions being asked (Zikmund, 2003). Under the first part, perceptions were sought about organization policy, auditees' cooperation and risk exposure of their respective organizations. In the second part, participants were asked about their perception towards their functions' ethics and objectivity (as determined by personal needs strength and leadership style) as internal audit practitioners. The final part contains questions on the respondents' profile. Instrument set (ii) is a questionnaire for collecting data on the views and perceptions of management on the role of internal audit in promoting transparency and accountability. Management's views can provide a better picture on corporate governance and internal audit practices and influences thereof (Cooper, et al., 1994). To this end, this questionnaire was aimed at obtaining the views and opinions of senior management on some aspects of internal audit practice and its influence on transparency and accountability. Management's views instead, as opposed to those of councilors who happen to be the policy makers were used for the purpose of this study. This is because management is responsible for the day to day operations of local authorities.

Management personnel possess knowledge of several dimensions of corporate governance due to the nature of their jobs, and internal audit operations due to their close working relationships with internal auditors. The councilors on the other hand represent board members who are appointment based on political merit and not on academic or professional competency (Kurebwa, 2015). As such, poor judgment and their lack of knowledge concerning corporate governance issues cannot be ruled out. Councilors by nature are not fulltime employees of the local authorities, their main role is to provide interface between the local authority and the communities they serve, performing policy overview and scrutiny, executive decision making, providing political leadership, determining planning implications and community representation. As such, they may lack requisite knowledge of internal audit operations. Therefore, the use of management personnel's views in this study helped in generating relevant data which is within the scope of research objectives. Instrument set (iii) is a document review checklist that guided the gathering of secondary data from various documentary sources. It specifies the documents that were reviewed and objectives of the review.

\section{Research hypothesis}

The study hypothesis was formulated on the basis of the strong link that exists between individual ethical values and their effect on moral choices and subsequent objectiveness of internal audit functions (Badaracco \& Ellsworth, 1991; Bauman, 2013; Woodbine \& Liu, 2010). Findings from a study by Woodbine \& Liu (2010), which supports the Path-Goal (House \& Mitchel, 1974) and the Existence Relatedness and Growth (Aldefer, 1972) theories concludes that the moral choices of internal auditors can be explained by their personal needs and reinforced by the leadership styles of their supervisors. (Woodbine \& Liu, 2010). These constructs collectively define the ethical nature of internal audit functions, which in turn has a leading impact on the function's objectivity. To assess the ethics and objectivity of an internal audit function and how it affects corporate governance, through selected measures as discussed above, the study hypothesis can be stated as follows:

$\mathrm{H} 2$ : Internal audit function ethics and objectivity is positively associated with transparency and accountability. Hypothesis two has other four sub-hypotheses stated here under:

$\mathrm{H} 2_{\mathrm{a}}$ : Internal audit function ethics and objectivity positively influences management perception towards internal auditors' capacity to impact on corporate governance practices.

$\mathrm{H} 2_{\mathrm{b}}$ : Internal audit function ethics and objectivity is positively associated with the existence of an organization policy authorizing internal audit.

$\mathrm{H} 2_{\mathrm{c}}$ : Internal audit function ethics and objectivity is positively associated with management cooperation.

$\mathrm{H} 2{ }_{\mathrm{d}}$ : The existence of an ethical and objective internal audit function is positively associated with the extent to which an organization is safeguarded against risk exposure.

\section{Research findings}

\subsection{Response rate and categorization of respondents}

Research data was obtained from a sample of 182 respondents composed of management and internal audit personnel from Zimbabwe local authorities. A total of 270 questionnaires had been distributed, of which 182 were 
successfully retuned containing useable data, giving a response rate of $67.4 \%$. This response rate is satisfactory considering response rates for similar prior related studies. Zaman \& Sarens (2013), in their study on the interaction between the Chief Audit Executive and the audit committee obtained a response rate of 27.8\% (Zaman \& Sarens, 2013), Alzeban \& Sawan, (2015), investigating the influence of audit committee on internal audit compliance with standards used a response rate of 46\% (Alzeban \& Sawan, 2015) and Leung \& Perera, (2011), during their survey on internal audit functions accountability structures and management relations in Australia used a response rate of $21.4 \%$ (Leung, et al., 2011). The level of participation is representative of the local government sub-sector as it was relative to the pro-rated distribution of questionnaires within local authorities (Table 2). In Zimbabwe there are 92 local authorities, categorized in to 60 Rural District Councils (RDCs) represented by 60,99\% of total participants, 7 City Councils represented by $9.89 \%$ of total participants, 8 Municipalities represented by $11.54 \%$ of total participants, 13 Town Councils represented by $10.99 \%$ of total participants and 4 Local Boards represented by $6.59 \%$ of total participants. As such, the sample of the study is capable of yielding results which are representative of the population and therefore findings can be deemed reliable.

Table 2: Categorization of respondents

\begin{tabular}{|l|c|c|}
\hline Local Authority Status & Participants & Distributed \\
\hline City Council & $18(9.89 \%)$ & $21(7.78 \%)$ \\
\hline Municipality & $21(11.54 \%)$ & $24(8.89 \%)$ \\
\hline Town Council & $20(10.99 \%)$ & $33(12.22 \%)$ \\
\hline Local Board & $12(6.59 \%)$ & $12(4.44 \%)$ \\
\hline Rural District Council & $111(60.99 \%)$ & $180(66.67 \%)$ \\
\hline
\end{tabular}

Source: Researcher, 2019

\subsection{Demographic profiles of respondents}

Analysis of demographic results (Table 3) indicate that management and internal audit positions in local authorities are dominated by males representing $63 \%$ of the total participants, whereas female participants represent $37 \%$ of total participants. As much as all the age ranges were represented, the age range 41-50 accounted for a greater number of participants, representing $52 \%$ of total participants

Table 3: Demographic information of respondents

\begin{tabular}{|c|c|c|c|c|c|c|c|c|c|c|}
\hline \multirow{3}{*}{$\begin{array}{l}\text { Age } \\
\text { group }\end{array}$} & \multirow[t]{3}{*}{ Gender } & \multicolumn{8}{|c|}{ LENGTH OF SERVICE IN YEARS } & \multirow[t]{3}{*}{ TOTAL } \\
\hline & & \multicolumn{2}{|c|}{ Less than 1 year } & \multicolumn{2}{|c|}{ 1-5 Years } & \multicolumn{2}{|c|}{ 6-10 Years } & \multicolumn{2}{|c|}{$\begin{array}{c}11 \text { YEARS \& } \\
\text { ABOVE }\end{array}$} & \\
\hline & & DIP & DEG & DIP & DEG & DIP & DEG & DIP & DEG & \\
\hline \multirow[t]{2}{*}{$<30$} & $\mathrm{M}$ & & & & 3 & 1 & & & & 4 \\
\hline & $\mathrm{F}$ & 1 & & 1 & & 1 & & & & 3 \\
\hline \multirow[t]{2}{*}{$30-40$} & $\mathrm{M}$ & & & 3 & & & 17 & & & 20 \\
\hline & $\mathrm{F}$ & & & & & 1 & & 3 & & 4 \\
\hline \multirow[t]{2}{*}{$41-50$} & $\mathrm{M}$ & 1 & & & 4 & 3 & 26 & 2 & 29 & 65 \\
\hline & $\mathrm{F}$ & & & 5 & & 1 & 2 & 7 & 15 & 30 \\
\hline \multirow[t]{2}{*}{$>50$} & $\mathrm{M}$ & & & & & & 19 & & 24 & 43 \\
\hline & $\mathrm{F}$ & & & & & & 5 & 1 & 7 & 13 \\
\hline TOTAL & & 2 & & 9 & 7 & 7 & 69 & 13 & 75 & 182 \\
\hline
\end{tabular}

Source: Researcher, 2019

\subsection{Reliability and validity}

The study adopted items measured on a Likert scale; therefore, reliability was assessed using the Cronbach's Alpha to assess internal consistency. Table 4 below shows the overall Cronbach's Alpha of 0.791 which is above the recommended threshold of 0.7 . This generally renders the instrument reliable for the study.

Table 4: Reliability Statistic (a)

\begin{tabular}{|l|l|l|}
\hline \multicolumn{2}{|c|}{ Reliability Statistics } \\
\hline Cronbach's Alpha & Cronbach's Alpha Based on Standardized Items & N of Items \\
\hline $\mathbf{0 . 7 9 1}$ & $0.851 \quad$ Scale Statistics & 72 \\
\hline \multicolumn{1}{|c|}{ Mean } & Variance & Std. Deviation \\
\hline $\mathbf{2 6 0 . 8 5}$ & $263.73 \quad 16.24$ \\
\hline
\end{tabular}

Source: Researcher, 2019

Table 5 below indicates Cronbach's Alpha for individual constructs. The independent variable ethics \& objectivity which is represented by Personal Needs Strength and Leadership Style variables had Cronbach's 
Alphas of 0,778 and 0.604 respectively. All the dimensions for transparency and accountability had Cronbach's Alphas ranging from 0.604 to 0.668 . The recommended Cronbach's Alpha threshold is 0.7 , however, a Cronbach's Alpha slightly below that is deemed satisfactory for an exploratory research (Hair, et al., 2010). This therefore means that all the constructs used for the purpose of this study are reliable.

Table 5: Reliability Statistics (b)

\begin{tabular}{|l|c|c|c|}
\hline Constructs & \multicolumn{3}{|c|}{ Reliability Statistics } \\
\cline { 2 - 4 } & $\begin{array}{c}\text { Cronbach's } \\
\text { Alpha }\end{array}$ & $\begin{array}{c}\text { Cronbach's Alpha Based on } \\
\text { Standardized Items }\end{array}$ & $\begin{array}{c}\text { N of } \\
\text { Items }\end{array}$ \\
\hline Personal Needs Strength & 0.778 & 0.783 & 8 \\
\hline Leadership Styles & 0.604 & 0.649 & 24 \\
\hline $\begin{array}{l}\text { Management Perception } \\
\text { Internal Audit }\end{array}$ & 0.668 & 0.735 & 4 \\
\hline $\begin{array}{l}\text { Organizational Policy authorizing } \\
\text { Internal Audit }\end{array}$ & 0.651 & 0.666 & 3 \\
\hline Auditee Cooperation & 0.633 & 0.635 & 5 \\
\hline Risk Exposure of the organization & 0.621 & 0.66 & \\
\hline
\end{tabular}

Source: Researcher, 2019

\subsection{Hypothesis testing}

We test the relationship between ethics \& objectivity and transparency \& accountability by using the Pearson correlation analysis and regression analysis. We re-stated the hypothesis here under:

H2: Internal audit function ethics \& objectivity is negatively associated with transparency \& accountability. We also test the sub-hypotheses re-stated here under:

H2a: Internal audit function ethics \& objectivity negatively influences management perception towards internal auditors' capacity to impact on corporate governance practices

H2b: Internal audit function ethics \& objectivity is negatively associated with organization policy authorizing internal audit

H2c: Internal audit function ethics \& objectivity is negatively associated with management cooperation

H2d: The existence of an ethical and objective internal audit function is negatively associated with the extent to which an organization is safeguarded against risk exposure.

\subsubsection{Correlation Analysis}

Correlation analysis is performed (Table 6) to show the relationship between internal audit function ethics \& objectivity measures (as the independent variable) namely personal needs strength and leadership style, and transparency \& accountability as the dependent variable measured by management perception towards internal audit, organization policy, auditees cooperation and risk exposure of the organization. The results show that there is a significant positive correlation between internal auditors' personal needs for existence and management perception of 0.341 , a significant positive correlation between internal auditors' needs for relatedness and management perception of 0.405 and a significant positive correlation between internal auditors' needs for growth and management perception of 0.391 . The correlations are significant at 0.01 . The results also indicate that there is no significant correlation between the Chief Audit Executive's leadership style and management perception towards internal auditors' capacity to impact on corporate governance practices. We therefore reject the null subhypothesis $\left(\mathrm{H} 2_{\mathrm{a}}\right.$ : Internal audit function ethics \& objectivity negatively influences management perception towards internal auditors' capacity to impact on corporate governance practices), and conclude that internal audit function ethics \& objectivity, as determined by internal auditors' personal needs strengths, positively influences management perception towards internal auditors' capacity to impact on corporate governance practices.

Correlation analysis between internal audit function ethics \& objectivity and organization policy show that there is a significant positive correlation between internal auditors' personal needs for existence and organization policy authorizing internal audit of 0.683; a significant positive correlation between internal auditors' needs for relatedness and the existence of an organization policy authorizing internal audit of 0.925 and a significant positive correlation between internal auditors' personal needs for growth and organization policy authorizing internal audit of 0.609 . The correlations are significant at 0.01 levels. The results also show that there is a significant negative correlation between the Chief Audit Executive's Standard Achievement leadership style and organization policy authorizing internal audit of -0.148 . The correlation being significant at 0.05 , we therefore reject the null subhypothesis $\left(\mathrm{H} 2_{\mathrm{b}}\right.$ : Internal audit function ethics \& objectivity is negatively associated with the existence of an organization policy authorizing internal audit), and conclude that internal audit function ethics \& objectivity as determined by internal auditors' personal needs strength, is positively associated with the existence of an organization policy authorizing internal audit.

Correlation between internal audit function ethics \& objectivity and auditees cooperation indicate that there is a significant positive correlation between internal auditors' personal needs for existence and auditees 
cooperation of 0.380 , a significant positive correlation between internal auditors needs for relatedness and auditees cooperation of 0.608 and a perfectly significant positive correlation between internal auditors' personal needs for growth and auditees cooperation. The correlations are significant at 0.01 . The results also show that there is no significant correlation between the Chief Audit Executive's leadership style and auditees' cooperation. We therefore reject the null sub-hypothesis $\left(\mathrm{H} 2_{\mathrm{c}}\right.$ : Internal audit function ethics \& objectivity is negatively associated with management cooperation), and conclude that internal audit function ethics \& objectivity as determined by internal auditors' personal needs strengths is positively associated with management cooperation.

Results also show that there is a significant positive correlation between internal auditors' personal needs for existence and risk exposure of the organization of 0.300 , a significant positive correlation between internal auditors' needs for relatedness and risk exposure of the organization of 0.486 and a significant positive correlation between internal auditors' personal needs for growth and risk exposure of the organization of 0.530 . The correlations are significant at 0.01 . The results also indicate that there is no significant correlation between the Chief Audit Executive's leadership style and risk exposure of the organization. We therefore reject the null sub-hypothesis $\left(\mathrm{H} 2_{\mathrm{d}}\right.$ : The existence of an ethical and objective internal audit function is negatively associated with the extent to which an organization is safeguarded against risk exposure), and conclude that the existence of an ethical and objective internal audit function is positively associated with the extent to which an organization is safeguarded against risk exposure. We can therefore conclude that internal audit function ethics and objectivity as determined by personal needs strength is positively associated with transparency and accountability in Zimbabwe local authorities.

Table 6: Correlation between Ethics \& Objectivity and Transparency \& Accountability

\begin{tabular}{|c|c|c|c|c|c|c|c|c|c|c|c|}
\hline & & $\begin{array}{l}\text { Organizationa } \\
\text { l policy }\end{array}$ & $\begin{array}{l}\text { Auditee } \\
\text { Cooperation }\end{array}$ & $\begin{array}{l}\text { Risk } \\
\text { Exposure }\end{array}$ & $\begin{array}{l}\text { Management } \\
\text { perspective }\end{array}$ & Existence & Relatedness & Growth & $\begin{array}{l}\text { Supportive } \\
\text { Leadership }\end{array}$ & $\begin{array}{l}\text { Participative } \\
\text { Leadership }\end{array}$ & $\begin{array}{l}\text { Directive } \\
\text { Leadership }\end{array}$ \\
\hline \multirow{2}{*}{$\begin{array}{l}\text { Organizationa } \\
1 \text { policy }\end{array}$} & \multicolumn{11}{|c|}{$\begin{array}{l}\text { Pearson Correlation } \\
\end{array}$} \\
\hline & Sig. (2-tailed) & & & & & & & & & & \\
\hline \multirow[t]{2}{*}{$\begin{array}{l}\text { Auditee } \\
\text { Cooperation }\end{array}$} & $\begin{array}{l}\text { Pearson } \\
\text { Correlation }\end{array}$ & $.609^{* *}$ & & & & & & & & & \\
\hline & Sig. (2-tailed) & 0 & & & & & & & & & \\
\hline \multirow[t]{2}{*}{$\begin{array}{l}\text { Risk } \\
\text { Exposure }\end{array}$} & $\begin{array}{l}\text { Pearson } \\
\text { Correlation }\end{array}$ & $.501^{* *}$ & $.530^{* *}$ & & & & & & & & \\
\hline & Sig. (2-tailed) & 0 & 0 & & & & & & & & \\
\hline \multirow[t]{2}{*}{$\begin{array}{l}\text { Management } \\
\text { perspective }\end{array}$} & $\begin{array}{l}\text { Pearson } \\
\text { Correlation }\end{array}$ & $.428^{* *}$ & $.391 * *$ & $.419^{* *}$ & & & & & & & \\
\hline & Sig. (2-tailed) & 0 & 0 & 0 & & & & & & & \\
\hline \multirow[t]{2}{*}{$\begin{array}{l}\text { Existence } \\
\end{array}$} & $\begin{array}{l}\text { Pearson } \\
\text { Correlation } \\
\end{array}$ & $.683^{* *}$ & $.380^{* *}$ & $.300^{* *}$ & $.341^{* *}$ & & & & & & \\
\hline & Sig. (2-tailed) & 0 & 0 & 0 & 0 & & & & & & \\
\hline \multirow[t]{2}{*}{ Relatedness } & $\begin{array}{l}\text { Pearson } \\
\text { Correlation } \\
\end{array}$ & $.925^{* *}$ & $.608^{* *}$ & $.486^{* *}$ & $.405^{* *}$ & $.426^{* *}$ & & & & & \\
\hline & Sig. (2-tailed) & 0 & 0 & 0 & 0 & 0 & & & & & \\
\hline \multirow[t]{2}{*}{ Growth } & $\begin{array}{l}\text { Pearson } \\
\text { Correlation }\end{array}$ & $.609^{* *}$ & $1.000^{* *}$ & $.530^{* *}$ & $.391^{* *}$ & $.380^{* *}$ & $.608^{* *}$ & & & & \\
\hline & Sig. (2-tailed) & 0 & 0 & 0 & 0 & 0 & 0 & & & & \\
\hline \multirow[t]{2}{*}{$\begin{array}{l}\text { Supportive } \\
\text { Leadership }\end{array}$} & $\begin{array}{l}\text { Pearson } \\
\text { Correlation } \\
\end{array}$ & 0.083 & 0.065 & 0.019 & 0.068 & 0.045 & 0.088 & 0.065 & & & \\
\hline & Sig. (2-tailed) & 0.225 & 0.342 & 0.777 & 0.317 & 0.511 & 0.194 & 0.342 & & & \\
\hline \multirow[t]{2}{*}{$\begin{array}{l}\text { Participative } \\
\text { Leadership }\end{array}$} & $\begin{array}{l}\text { Pearson } \\
\text { Correlation } \\
\end{array}$ & 0.02 & 0.037 & -0.032 & -0.095 & -0.065 & 0.033 & 0.037 & $.346^{* *}$ & & \\
\hline & Sig. (2-tailed) & 0.769 & 0.59 & 0.643 & 0.163 & 0.338 & 0.63 & 0.59 & 0 & & \\
\hline \multirow[t]{2}{*}{$\begin{array}{l}\text { Directive } \\
\text { Leadership }\end{array}$} & $\begin{array}{l}\text { Pearson } \\
\text { Correlation } \\
\end{array}$ & -0.043 & 0.01 & -0.098 & 0.003 & $-.179^{* *}$ & 0.035 & 0.01 & $.176^{* *}$ & $.177^{* *}$ & \\
\hline & Sig. (2-tailed) & 0.529 & 0.879 & 0.149 & 0.969 & 0.008 & 0.608 & 0.879 & 0.009 & 0.009 & \\
\hline \multirow[t]{2}{*}{$\begin{array}{l}\text { Standard } \\
\text { Achievement }\end{array}$} & $\begin{array}{l}\text { Pearson } \\
\text { Correlation }\end{array}$ & $-.148^{*}$ & -0.094 & -0.08 & -0.035 & -0.044 & $-.171^{*}$ & -0.094 & 0.054 & -0.044 & $.225^{* *}$ \\
\hline & Sig. (2-tailed) & 0.029 & 0.167 & 0.241 & 0.607 & 0.514 & 0.011 & 0.167 & 0.43 & 0.514 & 0.001 \\
\hline
\end{tabular}

\section{Source: Researcher,2019}

\subsubsection{Regression Analysis}

Table 7 below shows ANOVA results for Ethics and Objectivity as determined by personal needs strength and the Chief Audit Executive's leadership style as explanatory variables, with p-values of 0.00 and 0.286 respectively. The $\mathrm{p}$-value for Personal Needs Strength being significant at 0.05 helps us to conclude that Personal Needs Strength of internal auditors better explains management perception towards internal auditors' capacity to impact corporate governance practices than the Chief Audit Executive's leadership style. 
Table 7: ANOVA- Ethics \& Objectivity and Management Perception

\begin{tabular}{|l|l|c|c|c|c|c|}
\hline \multicolumn{9}{|c|}{ ANOVA } & S & Sig. \\
\hline Model & & Sum of Squares & df & Mean Square & F & S \\
\hline \multirow{3}{*}{ Personal Needs Strength } & Regression & 3142.933 & 3 & 1047.644 & 20.34 & $.000 \mathrm{~b}$ \\
\cline { 2 - 7 } & Residual & 11022.21 & 214 & 51.506 & & \\
\cline { 2 - 7 } & Total & 14165.14 & 217 & & & \\
\hline \multirow{3}{*}{ Leadership } & Regression & 327.732 & 4 & 81.933 & 1.261 & $.286 \mathrm{~b}$ \\
\cline { 2 - 7 } & Residual & 13837.41 & 213 & 64.964 & & \\
\cline { 2 - 7 } & Total & 14165.14 & 217 & & & \\
\hline
\end{tabular}

a Dependent Variable: Management perspective

b Predictors: (Constant), Personal Needs Strength, Leadership Style

Source: Researcher, 2019

By analyzing the results on table 8 below, it can be deduced that internal auditors' personal needs strength as key determinants of internal audit function's ethics and objectivity have positive results for existence (Beta 1.205), relatedness (Beta 1,097) and growth (Beta 1.025), all being significant at 0.05 . This means that internal auditors' personal needs strengths positively impacts management perception towards the internal auditors' capacity to impact on corporate governance practices. This leads to the conclusion of rejecting the null sub-hypothesis $\left(\mathrm{H} 2_{\mathrm{a}}\right)$ that internal audit function ethics \& objectivity negatively influences management perception towards internal auditors' capacity to impact corporate governance practices. However, results also show that the Chief Audit Executive's participative leadership style having a negative result (Beta -0.371) with (Sig 0.016) significance level means that the Chief Audit Executive participative leadership style negatively impacts management perception towards the internal auditors' capacity to impact corporate governance practices.

Table 8: Regression - Ethics \& Objectivity and Management Perception

\begin{tabular}{|c|c|c|c|c|c|c|}
\hline \multirow{2}{*}{\multicolumn{2}{|c|}{ Model }} & \multicolumn{2}{|c|}{$\begin{array}{l}\text { Unstandardized } \\
\text { Coefficients }\end{array}$} & \multirow{2}{*}{$\begin{array}{l}\text { Standardized } \\
\text { Coefficients } \\
\text { Beta } \\
\end{array}$} & \multirow[t]{2}{*}{$\mathrm{t}$} & \multirow[t]{2}{*}{ Sig. } \\
\hline & & $\mathrm{B}$ & Std. Error & & & \\
\hline \multirow{4}{*}{$\begin{array}{l}\text { Personal Needs } \\
\text { Strength }\end{array}$} & (Constant) & 59.13 & 4.986 & & 11.859 & 0.000 \\
\hline & Existence & 1.205 & 0.46 & 0.177 & 2.619 & 0.009 \\
\hline & Relatedness & 1.097 & 0.411 & 0.21 & 2.669 & 0.008 \\
\hline & Growth & 1.025 & 0.404 & 0.195 & 2.537 & 0.012 \\
\hline \multirow[t]{5}{*}{ Leadership } & (Constant) & 101.754 & 6.491 & & 15.675 & 0.000 \\
\hline & Supportive Leadership & 0.225 & 0.141 & 0.116 & 1.597 & 0.112 \\
\hline & $\begin{array}{l}\text { Participative } \\
\text { Leadership }\end{array}$ & -0.371 & 0.193 & -0.141 & -1.925 & 0.016 \\
\hline & Directive Leadership & 0.068 & 0.261 & 0.019 & 0.262 & 0.793 \\
\hline & Standard Achievement & -0.249 & 0.337 & -0.052 & -0.741 & 0.460 \\
\hline
\end{tabular}

Source: Researcher, 2019

Table 9 below shows ANOVA results for internal auditors' Personal Needs Strength and the Chief Audit Executive's Leadership Style having p-values 0.00 and 0.152 respectively. The p-values are significant at 0.05 , hence helping us to conclude that ethics and objectivity of an internal audit function being explained by internal auditors' personal needs strength better explains the existence of an organization policy authorizing internal audit as compared to leadership style of the Chief Audit Executive.

Table 9: ANOVA - Ethics \& Objectivity and Organization Policy

\begin{tabular}{|l|l|l|l|l|l|l|}
\hline \multicolumn{9}{|c|}{ ANOVA } & Sum of Squares & df & Mean Square & F & Sig. \\
\hline Model & Regression & 844.184 & 3 & 281.395 & 1613.536 & $.000 \mathrm{~b}$ \\
\hline \multirow{3}{*}{ Personal Needs Strength } & Residual & 37.321 & 214 & 0.174 & & \\
\cline { 2 - 8 } & Total & 881.505 & 217 & & & \\
\hline \multirow{2}{*}{ Leadership } & Regression & 27.24 & 4 & 6.81 & 1.698 & $.152 \mathrm{~b}$ \\
\cline { 2 - 8 } & Residual & 854.265 & 213 & 4.011 & & \\
\cline { 2 - 8 } & Total & 881.505 & 217 & & & \\
\hline
\end{tabular}

a Dependent Variable: Organization Policy

b Predictors: (Constant), Personal Needs Strength, Leadership Style

Source: Researcher, 2019

By analyzing results from table 10 below it can be revealed that Personal Needs Strength as an internal audit function ethics and objectivity determinant with positive results for existence (Beta 0.598) and relatedness (Beta 
1.004) being significant at 0.05 means that internal auditors' personal needs for existence and relatedness being the function's major ethics \& objectivity dimension, positively impacts the existence of an organization policy authorizing internal audit. This leads to the conclusion of rejecting the null sub-hypothesis $\left(\mathrm{H} 2{ }_{b}\right)$ that internal audit function ethics and objectivity is negatively associated with the existence of an organization policy authorizing internal audit. However, results also show that the Chief Audit Executive's participative and standard achievement leadership styles having a negative result (Beta -0.011) and (Beta -0.178) the results being significant at 0.05 means that the Chief Audit Executive's participative and standard achievement leadership styles negatively impacts the existence of an organization policy authorizing internal audit.

Table 10: Regression - Ethics \& Objectivity and Organization Policy

\begin{tabular}{|c|c|c|c|c|c|c|}
\hline \multicolumn{2}{|c|}{ Model } & \multicolumn{2}{|c|}{ Unstandardized Coefficients } & $\begin{array}{c}\text { Standardized } \\
\text { Coefficients } \\
\text { Beta } \\
\end{array}$ & $\mathrm{t}$ & Sig. \\
\hline \multirow{4}{*}{$\begin{array}{l}\text { Personal Needs } \\
\text { Strength }\end{array}$} & (Conctant) & 1024 & 020 & & 3528 & $0 \Omega 0$ \\
\hline & Existence & 0.598 & 0.027 & 0352 & 52338 & 0.00 \\
\hline & Relatedness & 1.004 & 0.024 & 0.771 & 41.972 & 0.00 \\
\hline & Growth & 0.008 & 0.024 & 0.006 & 0.323 & 0.75 \\
\hline \multirow[t]{5}{*}{ Leadership } & (Constant) & 19.236 & 1.613 & & 11.926 & 0.00 \\
\hline & Supportive & 0.049 & 0.035 & 0.101 & 1.389 & 0.07 \\
\hline & Participative & -0.011 & 0.048 & -0.017 & -0.236 & 0.01 \\
\hline & Directive & -0.022 & 0.065 & -0.024 & -0.341 & 0.73 \\
\hline & $\begin{array}{l}\text { Standard } \\
\text { Achievement }\end{array}$ & -0.178 & 0.084 & -0.148 & -2.132 & 0.03 \\
\hline
\end{tabular}

Source: Researcher, 2019

Table 11 below shows ANOVA results for internal auditors' Personal Needs Strength and the Chief Audit Executive's Leadership Style having p-values of 0.00 and 0.494 respectively. The p-value for personal needs strength being significant at 0.05 helps us to conclude that personal needs strength of internal auditors better explain the extent to which an organization is safeguarded against risk exposure than the Chief Audit Executive's leadership style.

Table 11: ANOVA- Ethics \& Objectivity and Risk Exposure

\begin{tabular}{|l|l|l|l|l|l|l|}
\hline \multicolumn{9}{|c|}{ ANOVA } & Sum of Squares & df & Mean Square & F & Sig. \\
\hline Model & Segression & 705.539 & 3 & 235.18 & 34.527 & $.000 \mathrm{~b}$ \\
\hline Personal Needs Strength & Residual & 1457.672 & 214 & 6.812 & & \\
\cline { 2 - 7 } & Total & 2163.211 & 217 & & & \\
\hline \multirow{2}{*}{ Leadership } & Regression & 34.022 & 4 & 8.505 & 0.851 & $.494 \mathrm{~b}$ \\
\cline { 2 - 7 } & Residual & 2129.189 & 213 & 9.996 & & \\
\cline { 2 - 7 } & Total & 2163.211 & 217 & & & \\
\hline
\end{tabular}

Source: Researcher, 2019

By analyzing the results on table 12 below it can be deduced that internal auditors' Personal Needs Strength as the key determinant of internal audit function ethics and objectivity have positive results for relatedness (Beta 0.493) and growth (Beta 0.00) being significant at 0.005. This means that internal auditor personal needs for relatedness and growth impacts the extent to which an organization is safeguarded against risk exposure. This leads us to the conclusion of rejecting the null sub-hypothesis $\left(\mathrm{H} 2{ }_{\mathrm{d}}\right)$ that the existence of an ethical and objective internal audit function is negatively associated with the extent to which an organization is safeguarded against risk exposure. 
Table 12: Regression - Ethics \& Objectivity and Risk Exposure

\begin{tabular}{|c|c|c|c|c|c|c|}
\hline \multirow{2}{*}{\multicolumn{2}{|c|}{ Model }} & \multicolumn{2}{|c|}{$\begin{array}{l}\text { Unstandardized } \\
\text { Coefficients }\end{array}$} & \multirow{2}{*}{$\begin{array}{l}\text { Standardized } \\
\text { Coefficients } \\
\text { Beta } \\
\end{array}$} & \multirow[t]{2}{*}{$\mathrm{T}$} & \multirow[t]{2}{*}{ Sig. } \\
\hline & & $\mathrm{B}$ & Std. Error & & & \\
\hline \multirow{4}{*}{$\begin{array}{l}\text { Personal } \\
\text { Needs } \\
\text { Strength }\end{array}$} & (Constant) & 2.54 & 1.813 & & 1.401 & 0.163 \\
\hline & Existence & 0.16 & 0.167 & 0.06 & 0.955 & 0.341 \\
\hline & Relatedness & 0.493 & 0.149 & 0.242 & 3.297 & 0.001 \\
\hline & Growth & 0.737 & 0.147 & 0.36 & 5.018 & 0.000 \\
\hline \multirow{5}{*}{$\begin{array}{l}\text { Leadersh } \\
\text { ip }\end{array}$} & (Constant) & 23.565 & 2.546 & & 9.255 & 0.000 \\
\hline & $\begin{array}{l}\text { Supportive } \\
\text { Leadership }\end{array}$ & 0.038 & 0.055 & 0.051 & 0.693 & 0.489 \\
\hline & $\begin{array}{l}\text { Participative } \\
\text { Leadership }\end{array}$ & -0.038 & 0.076 & -0.037 & -0.501 & 0.617 \\
\hline & $\begin{array}{l}\text { Directive } \\
\text { Leadership }\end{array}$ & -0.123 & 0.102 & -0.086 & -1.201 & 0.231 \\
\hline & $\begin{array}{l}\text { Standard } \\
\text { Achievement }\end{array}$ & -0.122 & 0.132 & -0.065 & -0.925 & 0.356 \\
\hline
\end{tabular}

Source: Researcher, 2019

From the regression analysis, we therefore conclude that there is a significant positive relationship between ethics \& objectivity of internal audit functions as determined by internal auditors' personal needs strength and transparency and accountability in Zimbabwe local authorities.

\section{Discussion}

The study findings revealed a positive relationship between internal audit function ethics and objectivity (measured by internal auditors' personal needs strength) and the effectiveness of internal auditors to impact transparency and accountability in Zimbabwe local authorities. Individual internal auditors' moral choices and values represents a crucial dimension of internal audit function objectivity in Zimbabwe local authorities considering the susceptibility of internal audit personnel to moral and ethical dilemmas. Study findings confirm conclusions by Woodbine and Liu (2010) that internal auditor's personal needs strength motivate their moral choices, enhancing objectivity and subsequently positively impacting corporate governance practices. In line with the conceptualized model, regression results confirm that internal auditors' needs for growth, relatedness and recognition play a leading role in shaping transparency and accountability in Zimbabwe local authorities. It is therefore important for principals within Zimbabwe local government subsector to ensure they are conscious of and invest towards addressing personal needs of internal auditors so that internal audit functions can judiciously exercise their mandates even under ethically conflicted environments and circumstances.

The current study did not explore other avenues potentially available to address the most wanted transparent accountability in Zimbabwe local authorities as it focused primarily on the determinants and the subsequent effects of moral choices of internal auditors on transparency \& accountability, hence the findings are not conclusive, as the possibility of having other ways of enhancing transparent \& accountability other than those associated with morally motivated decision making abilities of internal audit practitioners cannot be ruled out. However, moral decision making abilities of internal auditors significantly guarantee objectivity, hence the need to emphasize on ethics as a pillar of strength in our endeavor to enhance transparent accountability in Zimbabwe local authorities. Notwithstanding the important role played by an ethically and morally conscious internal auditor in promoting transparent accountability, an interesting revelation from the current exploration points to the notion that more still depends on the operational paradigms surrounding the internal audit profession in Zimbabwe local government subsector.

In Zimbabwe local authorities, internal audit is mandated by law and regulation, including the Constitution of Zimbabwe Amendment (No 20), The Public Finance Management Act (Chapter 22:19), The Public Entities Corporate Governance Act (10:31), the Urban Councils Act (29:15), and the Zimbabwe National Code on Corporate Governance which makes internal audit mandatory. However, there is no specification on the required nature of internal audit functions, besides that internal audit functions are expected to act in the best interest of the public. Nothing in these pronouncements speaks to the real meaning of acting in the interest of the public, thus, there are no specifications as to situations, circumstances and even the methodology guiding internal audit practitioners to professionally follow ethical conduct that has a public interest bias over and above the ethical levels of their respective local authorities. This scenario is mindboggling especially in cases where the general ethical environment and conduct of their respective local authorities is defective and against public interest. Following the model reporting structure in Zimbabwe local authorities, internal auditors technically leave it to 
management and the audit committee to disclose to the council wrongdoings or poor corporate governance practices unearthed by internal auditors. This is so because internal audit does not have direct access to the council, which represents the board, or any other external corporate governance enforcement agency. The current structure presents no room for internal audit functions to by-pass management and audit committee when the two choose not to disclose issues to the council, thus the operating paradigm might result in internal audit functions being blamed for causes beyond their rectification. This revelation however is in line with literature that points to the central nature of the role played by management in shaping the overall corporate governance nature of an organization (Adamec, et al., 2005; Ferrell \& Ferrell, 2011; Steinbauer, et al., 2014; Chambers \& Odar, 2015; Pearson \& Sutherland, 2017), as opposed to internal audit functions, whose role when not strategically positioned within an organization, will end up being more of a complementary management function.

\section{Conclusion}

The study investigated the impact of ethics \& objectivity of internal audit personnel on internal audit function capacity to impact transparency \& accountability in Zimbabwe local authorities. The study established that internal auditors' personal needs for existence, relatedness and growth determine their capacity to impact corporate governance practices. Local authorities in Zimbabwe need to be conscious and avail premises to uphold and promote personal needs of internal auditors in an endeavor to ensure internal audit functions objectively execute their mandate which has an effect of improving transparency \& accountability. The study did not explore the effects of other possible ways of enhancing transparency and accountability as it centered primarily on the capacity of audit practitioners to make ethical and moral decisions. However, the study established the need to improve operational paradigms guiding internal audit in Zimbabwe local authorities so as to empower internal audit functions and ensure they judiciously act in the best interest of the public, especially in circumstances where the general ethical conduct of their respective local authorities is defective and against public interest.

\section{References}

Abbort, L. \& Parker, S., 2000. Audit committee characteristics and audit choice. Auditing: A Journal of Practice and Theory, Vol. 19 No. 2, pp. 47-66.

Abu-Azza, W., 2012. Perceived effectiveness of the internal audit function in Lybia: a qualitative study using institutional and Marxist theories. s.1.:University of Southern Queensland.

Adamec, B. A., Leinicke, L. M., Ostrosky, J. A. \& Rexford, W. M., 2005. Getting a leg up. Internal Auditor, pp. 40-45.

Adams, M. B., 1994. Agency theory and the internal audit. Managerial Auditing Journal, 9(8), pp. 8-12.

Adiputra, P. M. I., Utama, S. \& Rossieta, H., 2018. Transparency of local government in Indonesia. Asian Journal of Accounting Research, Vol. 3 Issue. 1, pp. 123-138.

Ahmad, Z. \& Taylor, D., 2009. Commitment to independence by internal auditors: The effects of role ambiguity and role conflict. Managerial Accounting Journal, Vol 24, Issue 9, pp. 899-925.

Aldefer, C. P., 1972. Existance, Relatedness and Growth. New York: Free Press.

Al-Matari, E. M., Al-Swidi, A. K. \& Fadzil, H. F. B., 2014. The Effect of the Internal Audit and Firm Performance: A Proposed Reseach Framework. International Review of Management and Marketing, 4(1), pp. 34-41.

Al-Shabail, A. M. \& Turki, A. A. T., 2017. A theoratical discussion of internal audit effectiveness in Kuwaiti Industrial SMEs. International Journal of Accademic Research in Accounting, Finance and Management Sciences, 7(1), pp. 107-116.

Al-Twaijry, A. A., Brierley, J. A. \& Gwilliam, D. R., 2003. The development of internal auditing in Saudi Arabia: An institutional theory perspective.. Critical Perspectives on Accounting, 14(5), pp. 507-531.

Alzeban, A. \& Sawan, N., 2015. The impact of audit committee characteristics on the implementation of audit recommendations. Journal of International Accounting, Auditing and Taxation, Vol. 24 No. 1, pp. 61-71.

Archambeault, D. S., DeZoort, F. T. \& Holt, T. P., 2008. The need for an internal auditor report to external stakeholders to improve governance transparency. Accounting Horizons, Vol. 22 No. 4, pp. 375-389.

Arena, M., Arnaboldi, M. \& Azzone, G., 2006. Internal audit in Italian organisations: A multiple case study. Managerial Auditing Journal, 21(3), pp. 275-292.

Arena, M. \& Azzone, G., 2007. Internal audit departments: Adoption and characteristics in Italian companies. International Journal of Auditing, 11(2), pp. 91-114.

Arena, M. \& Azzone, G., 2009. Identifying organisational drivers of internal audit effectiveness. International Journal of Auditing, 13(1), pp. 43-60.

Arnold, D. F. S. \& Ponemon, L. A., 1991. Internal auditors' perceptions of whistle-blowing and the influence of moral reasoning an experiment. Auditing, A Journal of Practice and Theory, Vol. 10 No. 2, pp. 1-15.

Aziz, N. A. A., 2013. Managing corporate risk and achieving internal control through statutory compliance. Journal of Financial Crime, 20(1), pp. 25-38.

Badaracco, J. L. \& Ellsworth, R. R., 1991. Leadership, Integrity and Conflict.. Journal of Organizational Change 
Management, 4(4), pp. 46-55.

Bauman, D. C., 2013. Leadership and the three faces of integrity.. The Leadership Quarterly, 24(3), pp. 414-426.

Billington, R., 2003. Living philosophy: An introduction to moral thought. 3rd ed. London. UK: Routledge-Taylor \& Francis Group.

Bou-Raad, G., 2000. Internal Auditors and a value added approarch: A new business regime. Managerial Auditing Journal, pp. 182-186.

Brown, D., Mendenhall, S. \& Khamer, J., 2003. Business ethics programs: Is internal audit playing a proactive role?. Internal Auditing, Vol. 18 No. 4, pp. 28-32.

Caplan, D. H. \& Kirschenheiter, M., 2000. Outsourcing and audit risk for internal audit services.. Contemporary Accounting Research, 17(3), pp. 387-428.

Carmichael, D. R., 2004. The PCAOB and the social responsibility of the auditor. Accounting Horizons, 18(2), pp. 127-133.

Carruthers, B. G., 1995. Accounting ambiguity and the new institutionalism. Accounting, Organisation and Society, Vol. 20 No. 4, pp. 313-328.

Caswell, B. \& Allen, C., 2001. The engagement team approarch to independence. Journal of Accountancy, 191(2), pp. 57-63.

Chambers, A. D. \& Odar, M., 2015. A new vision for internal audit. Managerial Auditing Journal, Vol. 30 Issue. 1, pp. 34-55.

Chatiza, K., 2008. Opportunities and Challenges in Institutional Participation Development: The case of Rural Zimbabwe.. s.l.:Unpublished PhD Thesis.

CHRA, 2014. The green paper of Zimbabwe Local Government. Harare: Combined Harare Residents Association.

CHRA, 2014. The green paper of Zimbabwe's local government. Harare: Combined Harare Residents Association.

Christopher, J., 2014. Internal Audit: Does it enhance governance in the Australian University Sector?. Education Management Aministration and Leadership, pp. 1-18.

Christopher, J., Sarens, G. \& Leung, P., 2009. A critical analysis of the independence of the internal audit function: Evidence from Australia. Accounting, Auditing \& Accountability Journal, Vol, 22 Issue. 2, pp. 200-220.

Christopher, J., Sarens, G. \& Leung, P., 2009. A critical analysis of the independence of the internal audit function: Evidence from Australia.. Accounting,Auditing and Accountability Journal, Vol 22 (2), pp. 200-220.

Clayton, A., Oakley, P. \& Taylor, J., 2000. Civil Society Organisations and Service Provision. s.1.:Programe Paper Number 2.

Coetzee, P. \& Lubbe, D., 2014. Improving the efficiency and effectiveness of risk based internal audit engagements. International Journal of Auditing, Vol. 18 No. 2, pp. 115-125.

Cohen, A. \& Sayag, G., 2010. The effectiveness of internal auditing: An empirical examination of its determinants in Israeli organisations. Australian Accounting Review, pp. 296-307.

Cooper, B. J. \& Craig, J., 1983. A Profile of Internal Audit in Australia. Melbourne: Royal Melbourne Institute of Technology.

Cooper, B. J., Leung, P. \& Mathew, C., 1994. Internal audit: An Ausitralian profile. Managerial Auditing Journal, 9(3), pp. 13-19.

Cooper, B. J., Leung, P. \& Mathews, C. M. H., 1996. Benchmarking - A comparison of internal audit in Australia, Malaysia and Hong Kong. Managerial Auditing Journal, Volume 11(1), pp. 23-29.

Dal Mas, L. O. \& Barac, K., 2018. The influence of chief audit executive's leadership style on factors related to internal audit effectiveness. Manajerial Auditing Journal, Vol. 33 Issue:8/9, pp. 807-835.

DeAngelo, L. E., 1981. Auditor size and audit quality. Journal of Accountancy \& Economics, Volume 3, pp. 183199.

Deegan, C. \& Unerman, J., 2006. Financial Accounting Theory. s.1.:McGraw-Hill Education.

Deloitte, 2010. The brocken triangle? Improving the relationship between internal audit, management and the audit committee.

Demidenko, E. \& McNutt, P., 2010. The ethics of enterprise risk management as a key component of corporate governance. International Journal of Social Economics, Vol. 37 Issue. 10, pp. 802-815.

DeZoort, F. T., Houston, R. W. \& Peters, M. F., 2001. The impact of internal auditor compensation and role on external auditors' planning judgements and decisions. Contemporary Accounting Research, Vol. 18 No. 2, pp. 257-281.

DiMaggio, P. J. \& Powell, W. W., 1983. The iron cage revisited: Institutional isomorphism and collective rationally in organisational field. American Sociological Review, Volume 48, pp. 147-160.

DiMaggio, P. J. \& Powel, W. W., 1983. The iron cage revisited: Instituitional Isomorphism and Collective rationality in organisational fields.. American Sociological Review, 48(2), pp. 147-160.

Dittenhoffer, M. A. \& Klemn, R. J., 1983. Ethics and the internal auditor. Altamonte Springs, FL: The Institute of Internal Auditors.

Dittenhoffer, M. A. \& Sennetti, J. T., 1994. Ethics and the internal auditor, Ten years later. Altamonte Springs, FL: 
The Institute of Internal Auditors.

Ekanayake, S., 2004. Agency theory, national culture and management control systems. Journal of American Academy of Business, Volume 4, pp. 49-54.

Erasmus, L. \& Coetzee, P., 2018. Drivers of stakeholders' view of internal audit effectiveness: Management versus audit committee. Managerial Auditing Journal, Vol. 33 No. 1, pp. 90-114.

Evans, L., 2003. Auditing and audit firms in German before 1931. The Accounting Historians Journal, 30(2), pp. 29-65.

Everett, J. \& Tremblay, M. S., 2014. Ethics and internal audit: moral will and moral skill in a heteronomous field. Critical Perspectives on Accounting, Vol 25 No. 1, pp. 181-196.

Falkman, P. \& Tagesson, T., 2008. Accrual accounting does not necessarily mean accrual accounting: Factors that counteract compliance with accounting standards in Swedish municipal accounting. Scandinavian Journal of Management, Vol. 24 No. 2, pp. 271-283.

Fama, E. F. \& Jensen, M. C., 1983. Separation of ownership and control. Journal of Law and Economics, Volume 26, pp. 301-325.

Ferrell, O. C. \& Ferrell, L., 2011. The responsibility and accountability of CEOs: The last interview with Ken Lay. Journal of Business Ethics, Vol. 100 Issue. 2, pp. 209-219.

Gabrini, C. J., 2013. The effect of internal audit on governance: Mantaining legitimacy of local government. s.1.:Florida State University Libraries.

Goodwin, J. \& Yeo, T. Y., 2001. Two factors affecting internal audit independence and objectivity: Evidence from Singapore. International Journal of Auditing, Vol. 5 No. 2, pp. 107-125.

Goodwin, J. \& Yeo, T. Y., 2001. Two factors affecting internal audit independence and objetcivity.. International Journal of Auditing Vol 5 (2), pp. 107-125.

Goodwin-Stewart, J. \& Kent, P., 2006. The use of internal audit by Australian companies. Managerial Auditing Journal, 21(1), pp. 81-101.

Gramlin, A. A., Maletta, M. J., Schneider, A. \& Church, B. K., 2004. The role of the internal audit function in corporate governance: A synthesis of the extent of internal audit literature and directions for future research.. Journal of Accounting Literature, Vol 23, pp. 192-244.

GrantThornton, 2015. Competing priorities: are CAE and audite committee priorities sync?.

Hair, J. F., Black, W. C., Babin, B. J. \& Anderson, R. E., 2010. Multivariate Data Analysis, 7th edn. Eaglewood Cliffs, Upper Saddle River, NJ: Prentice Hall.

Hair, J. F., Black, W. C., Babin, B. J. \& Anderson, R. E., 2010. Multivariate Data Analysis, 7th. edn. Eaglewood Cliffs, Upper Saddle River, NJ: Prentice Hall.

Halimah, N. A., Othman, R. \& Kamaruzaman, J., 2009. The effectiveness of internal audit in Malaysian Public Sector.. Journal of Modern Accounting and Auditing, Vol 5 (9), pp. 53-62.

Hall, A. T. \& Ferris, G. R., 2011. Accountability and extra-role behaviours. Employee Responsibilities \& Rights Journal, Vol. 23 No. 2, pp. 131-144.

Hall, A. T., Frink, D. D. \& Buckley, M. R., 2015. An accounntability account: A review and sythesis of the theoretical and empirical research on felt accountability. Journal of Organisation Behaviour.

Holt, T. P. \& DeZoort, T., 2009. The effects of internal audit report disclosure on investors confidence and investment decisions. International Journal of Auditing, 13(1), pp. 61-77.

Hope, T., 2004. Medical ethics: A very short introduction. New York, NY: Oxford Unversity Press.

House, R. J. \& Mitchel, T. R., 1974. Path-Goal Theory of Leadership. Joutnal of Contemporary Business, p. 3.

Hutchinson, M. \& Zain, M., 2009. Internal audit quality, audit committee independence, growth opportunities and firm performance. Corporate Ownership and Control, 7(2), pp. 50-63.

Ibrahim, E. S. E., 2011. Corporate governance practices and auditor's client acceptance decision: Evidence from Egypt. Corporate Governance, Vol. 11 Issue. 2, pp. 171-183.

IIA., 2014. The pulse of the profession - enhancing value through collaboration.

IIA, 2016. Definition of Internal Auditing. USA: Institute of Internal Auditors.

Jennnings, M. M., 2003. The ritical role of ethics. Internal Auditor, Vol. 60 No. 6, pp. 46-51.

Jensen, M. C. \& Meckling, W. H., 1976. Theory of the firm: Managerial behavior,agency cost and ownership structure. Journal of Financial Economics, 3(4), pp. 305-360.

Jiang, L., Andre, P. \& Richard, C., 2014. Determinants of Internal Audit Function Quality: An International study. s.l.:ESSEC Business School.

Kauzya, J. M. \& Balogun, J., 2005. Governance and public administration reforms and innovations in African countries: A focus on achievements, setbacks and future directions. Lagos: Key Press.

Kimotho, N. T., 2014. Factors affecting internal audit independence: A case study of Technical University of Mombasa.. Journal of Business \& Management, 6(6).

Kinicki, A. \& Williams, B. K., 2013. Management: A practical introduction, 6th ed. New York, NY: McGraw Hill Irwin. 
Kurebwa, J., 2015. A Review of Rural Local Government in Zimbabwe from 1980 - 2014. IOSR Journal of Humanities and Social Sciences, Vol 20 Issue. 2, pp. 94-108.

Larking, J. M., 2000. The ability of internal auditors to identify ethical dilemas. Journal of Business Ethics, Vol. 23 No. 4, pp. 401-409.

Leung, P., Cooper, B. \& Perera, L., 2011. Accountability structures and management relationships of internal audit: An Australian study. Managerial Auditing Journal, Vol. 26 No. 9, pp. 794-816.

Limperg institute, 1985. The social responsibility of the auditor. A basic theory on the auditor's function. Amstedam: Limperg Institute.

Lindberg, S. I., 2013. Mapping accountability: Core concepts and subtypes. International reviews of Administrative Science, Vol. 79 No. 2, pp. 202-226.

MacDougall, A. E., Bagdasarov, Z., Johnson, J. F. \& Mumford, M. D., 2015. Managing workplace ethics: An extended conceptualisation of ethical sensemaking and the facilitative role of human resources. Research in Personnel and Human Resource Management, pp. 121-189.

Mapuwa, J., 2011. Enhancing local governance through local initiatives: Residents Associations in Zimbabwe. African Journal of Scientific \& Research Publications. Volume 6 (11).

Messier, J. \& Schneider, A., 1988. A hierarchical approarch to the external auditor's evaluation of the internal audit function.. Contemporary Accounting Research, 4(2), pp. 337-353.

Mezias, S., 1990. An institutional model of organisational practice: Financial reporting at the fortune 200. Administrative Science Quarterly, Volume 35, pp. 431-457.

Mihret, D. G., James, K. \& Mula, J. M., 2010. Antecedents and organisational performance implications of internal audit effectiveness: some propositions and research agenda. Pacific Accounting Review, pp. 224-252.

Mihret, D. G., Mula, J. M. \& James, K., 2012. The development of internal auditing in Ethiopia: The role of institutional norms. Journal of Financial Reporting and Accounting, 10(2), pp. 153-170.

Mihret, D. G. \& Yismaw, A. w., 2007. Inernal Audit Effectiveness: An Ethiopian public sector case study.. Managerial Auditing Journal, pp. 470-484.

Moeller, R., 2004. Managing internal audit in a post-SOA world. The Journal of Corporate Accounting and Finance, Vol. 15 No. 4, pp. 41-45.

Myers, P. M. \& Gramlin, A. A., 1997. The perceived benefits of certified internal auditor designation.. Managerial Auditing Journal, Vol. 12 (2), pp. 70-79.

Neu, D., Evereett, J. \& Rahaman, A. S., 2013. Internal auditing and corruption within government: The case of Canadian sponsorshop program. Contemporary Accounting Research, Vol. 30 No. 3, pp. 1223-1250.

Neu, D., Everett, J. \& Rahaman, A. S., 2013. Internal auditing and corruption within government: The case of Canadian sponsorship program. Contemporary Accounting Research, Vol. 30 No. 3, pp. 1223-1250.

Noble, C., 2010. Managing the support stuff identity crisis. Boston: Harvard Business School.

Norman, C. S., Rose, A. M. \& Rose, J. M., 2010. Internal auditing reporting lines, fraud risk decomposition ans assessment of fraud risk.. Accounting, Organisation and Society, Vol 35 (5), pp. 546-557.

O'Leary, C. \& Stewart, J., 2007. Governance factors affecting internal auditors' ethical decision making. An exploratory study. Managerial Auditing Journal, Vol. 22 Issue. 8, pp. 787-808.

Paape, L., Scheffe, L. \& Snoep, P., 2003. The relationship between the internal audit function and corporate governance in the EU - A survey. International Journal of Auditing, Vol. 7, pp. 247-267.

Pearson, H. \& Sutherland, M., 2017. The comlexity of the antecedents influencing accountability in organisations. Europian Business Review, Vol. 20 Issue. 4, pp. 419-439.

Pearson, H. \& sutherland, M., 2017. The complexity of the antecedents influencing accountability in organisations. European Business Review, Vol. 29 Issue. 4, pp. 419-439.

Pina, V., Torres, L. \& Royo, S., 2010. Is e-government promoting converge towards more accountable local government?. International Public Management Journal, Vol. 13 No. 4, pp. 350-380.

Pinnington, A., Macklin, R. \& Campbell, T., 2007. Human Resource Management: Ethics and Employment. Oxford, NY: Oxford University Press.

Piotrowski, S. J. \& Bartelli, A., 2010. Measuring municipal transparency. s.1., s.n.

Pizzini, M., Lin, S. \& Ziegenfuss, D., 2015. The impact of internal audit function quality and contribution on audit delay. Auditing: A Journal of Practice and Theory, Vol. 34 No. 1, pp. 25-58.

Ponemon, L. \& Gabhart, D., 1993. Ethical reasoning in Accounting and Auditing. s.1.:s.n.

Prawitt, D., Smith, J. \& Wood, D., 2009. Internal audit quality and earnings management. The Accounting Review, Vol. 84. No. 4, pp. 1255-1280.

PwC, 2014. 2014 State of the internal audit profession study - higher performance by design: a blue print for change.

Reed, D., 2002. Employing normative stakeholder theory in developing countries a critical theory perspective.. Business and Society, 41(2), pp. 166-207.

Regoliosi, C. \& D'eri, A., 2014. 'Good' corporate governance and the quality of internal audit departments in Italian 
listed firms. An exploratory investigation in Italian listed firms. Journal of Management and Governance, Vol. 18 No 3, pp. 891-920.

Rizzotti, D. \& Greco, A., 2013. Determinants of board of statutory auditorsand internal control committee deligence: a comparison between audit committee and the corresponding Italian committees. The International Journal of Accounting, Vol. 30 No. 1, pp. 84-110.

Roussy, M., 2015. Welcome to the day-to-day of internal auditors: How do they cope with conflicts?. Auditing: A Journal of Practice \& Theorry, Vol. 34 No. 2, pp. 237-264.

Roussy, M. \& Brivot, M., 2016. Internal audit quality: a polysemous notion?. Accounting, Auditing and Accountability Journal, Vol. 29 No. 5, pp. 714-738.

Roussy, M. \& Brivot, M., 2016. Internal audit quality: a polysemous notion?. Accounting, Auditing amnd Accountability Journal, Vol. 29 No. 5, pp. 714-738.

Salehi, M., 2011. Audit expectation gap: Concept, nature and trace.. Afracan Journal of Business Management, 5(21), pp. 8376-8392.

Sarens, G., Allegrini, M., D'Onza, G. \& Melville, R., 2011. Are internal auditing practices related to the age of the internal audit function? Exploratory evidence and directions for future research. Managerial Auditing Journal, Vol. 26 No. 1, pp. 51-64.

Sarens, G. \& Christopher, J., 2010. The association between corporate governance guidelines and risk management and internal control policiea: Evidence from a comparative study. Managerial Auditing Journal, Vol. 25 Issue. 4, pp. 288-308.

Sarens, G. \& De Beelde, I., 2006a. Internal auditors' perceptions about their role and risk management.. Managerial Auditing Journal, Vol 21 (1), pp. 63-80.

Sarens, G. \& De Beelde, I., 2006. Internal auditors' perception about their role in risk management: A comparison bwtween US and Belgian companies.. Managerial Auditing Journal, 21(1), pp. 63-80.

Sawyer, L. B., 1995. An internal audit philosophy. Internal Auditor, pp. 46-55.

Schneider, A., 2003. An examination of whether incentive compansation and stock ownership affect internal audit objectivity. Journal of Managerial Issues, Volume XV (4), pp. 486-497.

Schneider, A., 2010. Determining whether there are any effects of incentive compensation and stock ownweship on internal audit procedures. International Journal of Auditing, Vol. 14 No. 1, pp. 101-110.

Shabnan, F. A., Zakiah, M. M. \& Azlina, A., 2014. The effects of personal and organisational factors on role ambiguity amongst internal auditors. International Journal of Auditing, Vol 18. No 2, pp. 105-114.

Sherer, M. \& Kent, D., 1983. Auditing and Accountability. London: Pitman.

Sison, A. J. G. \& Fontrodona, J., 2012. The common good of the firm in the Aristotelian-Thomistic tradition. Business Ethics Quarterly, Vol.22 No. 2, pp. 211-246.

Steinbauer, R., Renn, R. W., Taylor, R. R. \& Njoroge, P. K., 2014. Ethical leadership and followers' moral judgement: The role of followers' perceived accountability and self leadership. Journal of Business Ethics, Vol. 120 No. 3, pp. 381-392.

Steinbauer, R., Renn, R. W., Taylor, R. R. \& Noronge, P. K., 2014. Ethicals leadership and followers' moral judgement and self-leading. Journal of Business Ethics, Vol. 120 Issue. 3, pp. 381-392.

Stewart, J. \& Subramaniam, N., 2010. Internal audit independence and objectivity: Emerging research opportunities. Managerial Auditing Journal, Volume 25, p. 328.

Thompson, C., 2003. Fraud findings: Wilful blindness. International Journal of Auditing, Vol. 60 No. 3, pp. 71-73.

Thorne, L., 2000. The development of context-specific measures of accountants' ethical reasoning. Behavioral Research in Accounting, Vol. 12 No. 1, pp. 139-170.

Trotman, A. J. \& Trotman, K. T., 2015. Internal audit's role in GHG emissions and energy reporting. Evidence from audit committees, senior accountants and internal auditors. Auditing: A Journal of Practice and Theory. Vol. 34 No1, pp. 199-230

Van Gansberhe, C. N., 2005. Internal Auditing in the public sector: A consultative forum in Nairobi, Kenya, shores up best practices for government audit professionals in developing nations. Internal Auditor, pp. 69-73.

Venasco, R. R., 1994. The IIA code of ethics: An international perspective. Managerial Auditing Journal, Vol. 9 (1), pp. 12-22.

Venasco, R. R., 1994. The IIA code of ethics: An international perspective. Managerial Auditing Journal, Vol 9 (1), pp. $12-22$.

Vinnari, E. \& Skaebaek, P., 2014. the uncertainties of risk management: a field study on risk management internal audit practicesin a Finnish municipality. Accounting, Auditing and Accountability Journal, Vol. 27 No. 3, pp. 489-726.

Vinten, G., 1999. Auditor Independence in the UK - the state of the art. Managerial Auditing Journal, Vol 14 (8), pp. 408-437.

West, A., 2017. The ethics of professional accountants: An aristotelian perspective. Accounting, Auditing and Accountability Journal, Vol. 30 Issue. 2, pp. 328-351. 
Willekens, M., Vander Bauwhede, H. \& Gaeremynck, A., 2004. Voluntary audit committee formation and practice among Belgian listed companies. International Journal of Auditing, Vol. 8 No. 3, pp. 207-222.

Woodbine, F. G. \& Liu, J., 2010. Leadership styles and the moral choice of internal auditors. Electronic Journal of Business Ethics and Organisation Studies, 15(1), pp. 28-35.

Yeoh, E. \& Jubb, C. A., 2001. Governance and Audit Quality: Is there an Association?. s.1.:University of Melbourne.

Zaman, M. \& Sarens, G., 2013. Informal interactions between audit committees and internal audit functions: exploratory evidence and directions for future research. Managerial Auditing Journal, Vol. 20 No. 6, pp. 495 515.

Zikmund, W. G., 2003. Business research methods. 7th ed. South-Western USA: Thomson.

First Author - Moses Jachi

After a distinguished career as an Internal Auditor in the Zimbabwean Local Government sub-sector, which saw him rising to the rank of Chief Audit Executive in two different Local Authorities, Moses Jachi joined the academic career at Manicaland State University of Applied Sciences as an Accounting Lecturer. He is a Certified Public Accountant (CPA) and is registered with the Public Accountants and Auditors Board (PAAB) of Zimbabwe as a Public Accountant. He is a $\mathrm{PhD}$ student and his research concentrates on internal audit quality and corporate governance in the public sector. He is currently teaching, researching and/ supervising aspects of Auditing, Financial Reporting and Public Sector Accounting and research at undergraduate level.

\section{Second Author- Lucky Yona}

Lucky Yona is a Professor of Finance and Director of Research and Publication at Eastern and African Management Institute (ESAMI) in Tanzania He holds a Phd in Finance ( Euraka European University), a Doctorate degree in Business Administration (DBA) and MPhil degree from MsM(Netherlands), MBA in Finance (MsM/ESAMI), Bcom (Accounting) degree from University of Dar-es-Salaamam B.Th. (Christian Life School of Theology-Georgia, -USA): Lucky is also a Certified Public Accountant (CPA)and a member of Tanzania National Board of Accountants (NBAA). 